Гоголь в зеркале русского модернизма

Аннотация: В статье рассматриваются особенности восприятия личности и творчества Н.В. Гоголя в России на рубеже XIX-XX вв. и отражена динамика меняющегося отношения к писателю в России в первое десятилетие XX в. В центре внимания оценки, которые давали Гоголю русские модернисты. Показано, что его трагическая судьба для модернистов первой волны - старших символистов - стала важным аргументом в спорах с православным духовенством о сущности религиозного идеала. Младосимволисты иначе воспринимали Гоголя и находили в его личной и творческой судьбе ответы на актуальные для них вопросы.

Ключевые слова: Гоголь, модернизм, старшие символисты, младосимволисты, интеллигенция и Церковь

E.A. Pevak (Moscow, Russia)

\title{
Gogol in the Mirror of Russian Modernism
}

Abstract: The article discusses perception of personality and creativity of Nikolai Gogol in Russia at the turn of the $19-20^{\text {th }}$ centuries and shows the dynamics of the changing attitude towards the writer in Russia in the first decade of the $20^{\text {th }}$ century. In the center of the analysis are the assessments given to this writer by Russian modernists. It is shown that the tragic fate of Gogol for the modernists of the first wave - the senior symbolists - became an important argument in disputes with the Orthodox clergy about the essence of the religious ideal. The younger symbolists otherwise perceived Gogol and found in his personal and creative fate the answers for their actual questions.

Key words: Gogol, modernism, the senior symbolists, the younger symbolists, Russian intelligentsia and Church

Русский модернизм - явление уникальное. Появившийся во многом как результат влияния новейших тенденций в европейской культуре второй половины XIX в. на русское искусство и русскую общественную мысль, русский модернизм основательным образом переработал заимствованные тезисы и приемы, наполнив их специфически русским содержанием, главным элементом которого является по-своему понятый религиозный идеал, проецируемый в том числе и на эстетическую проблематику, не ограничиваясь сферой нравственно-психологической. 
На этапе формирования эстетической концепции модернизма в России представители нового искусства были далеки, по крайней мере на словах, от традиционного христианства, декларируя отказ от нравственных догм, собственного говоря, выступая с позиций воинствующего аморализма. Атмосферу, царящую в собраниях декадентствующих модернистов в первые годы их существования, охарактеризовал свидетель и участник процесса созидания нового русского искусства А.Н. Бенуа. О первых своих встречах с Д.С. Мережковским и его тогдашним окружением он писал в «Моих воспоминаниях»: «Не могу сказать, что... первое посещение Мережковских оставило во мне приятное впечатление. Это была пора характерного fin de siècle, прециозность и передовитость которого выражалась в культе (на словах) всего порочного с примесью всякой мистики, нередко роднившейся с мистификацией» ${ }^{1}$. Добавим к этому и всеобщее увлечение философией Ницше, готовность игнорировать происходящие в обществе социально-политические процессы и сосредоточенность на проблемах прежде всего индивидуального бытия. Казалось, очерченный представителями нового русского искусства круг вопросов не предполагал пробуждения и стойкого интереса к автору, которому по самой природе его чужды были идейные и эстетические установки литературных наследников. Но, видимо, именно мистицизм Гоголя, вне контекста Православия, дал толчок к исследованию представителями модернизма в России феномена личности Гоголя и ее отражения в созданных этим писателем произведениях. В то же время мистическое обоснование анархического бунта индивидуальности, пропагандируемое символистами в первую очередь, как в статьях, так и в художественных произведениях, не позволяет ставить знак равенства между мистикой Гоголя и опытами его так называемых последователей из числа представителей нового искусства. Ярче всего конфликт, всегда существовавший между Гоголем и творческой интеллигенцией Серебряного века, отражен в оценке Н.А. Бердяева («Русская идея»), увидевшего в гоголевской доктрине социального христианства «низменную» и «рабью» утопию, где идея свободы личности и вообще дух свободы вытеснены мещанской моралью, подавляются проповедью авторитаризма. В уже названной работе Бердяев указывает на сходство судьбы Гоголя с драмой Боттичелли, поддавшегося идеям Саванаролы, или Расина, пленника янсенизма (к слову сказать, этот мотив неоднократно появлялся на рубеже XIX-XX вв. в обсуждениях гоголевской темы и связанной с ней проблематики). И в том и в другом случае речь идет об отсутствии внутренней свободы и о добровольном рабстве, которое несовместимо с творчеством - свободным волеизъявлением художника. Неудивительно, что, размышляя о судьбе Гоголя, писатели и поэты, исповедующие идеологию свободы творческого «я», сосредоточились на проблеме взаимоотношений Гоголя с о. Матвеем, ржевским протоиреем, сыгравшим, как им казалось, роковую роль в судьбе писателя. В этом факте биографии Гоголя сошлись сразу несколько линий, которые вплетены и в споры о взаимоотношениях интеллигенции и Церкви, и в поиски выхода из кризиса творческого, источником которого, как и у Гоголя, стала установка на отказ от собственно художественных задач и погружение в прозелитизм, а затем и отождествление творческого начала с богоборческим. Эти проблемы отвлеченного характера становились конкретикой, когда материалом для их анализа оказывалась судьба писателя, обратившего свой творческий поиск в поиск духовный.

\footnotetext{
${ }^{1}$ Бенуа А.Н. Мои воспоминания: В 5 кн. Книги четвертая, пятая. 2-е изд., доп. М.: Наука, 1990. C. $47-48$.
} 
Показательно, что тема Гоголя и о. Матвея возникает уже на первом заседании Религиозно-философских собраний (1901) - в прениях по докладу «Русская церковь пред великою задачей», прочитанному В.А. Тернавцевым. Обратился к этой теме еп. Сергий, упомянув опубликованную в «Новом времени» заметку И.Л. Леонтьева-Щеглова «Гоголь и о. Матвей Константиновский» и остановив внимание собравшихся на том, что «интеллигенция не доверяет искренности

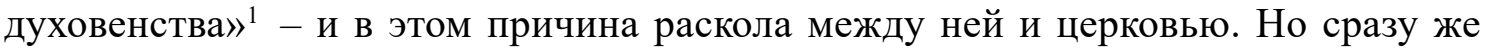
обнаружилась еще одна проблемная точка несхождения двух позиций - интеллигенции и духовенства, имеющая самое непосредственное отношение к творческой практике писателей нового поколения, ставивших перед собой цель «ознаменовать» явления действительности, обнаружив в них скрытые от неискушенных взоров людей, далеких от творчества, отблески вечности. Отстраненность Церкви от земной жизни, игнорирование всех тех проблем, которые имеют отношение к плоти, - в этом, по мнению представителей русской интеллигенции модернистского уклона, и заключался главный порок христианства, которое учит умирать, но не помогает жить. Позиционируя себя как идеалистов в сфере творчества, русские модернисты в то же время едва ли не с первых дней своего существования были настроены на то, чтобы и реальный мир был привлечен в качестве материала для их творчества. Но в отличие от реалистов, которые занимали в русской литературе ключевые позиции в предшествующий период (во второй половине XIX в.) и ограничивались в большей степени фиксацией явлений действительности (так воспринимали их творчество модернисты), литераторы нового поколения призывали, усвоив те достижения, которыми обогатил искусство реализм, сделать следующий шаг - научиться видеть не только поверхностный слой реальности, но открывать таящееся под ним мистическое содержание жизни, используя для этого символы, которые должны «естественно и невольно выливаться из глубины действительности» ${ }^{2}$.

Понять сложность и значимость поставленной ими задачи поможет детальное ее разъяснение теоретиком символизма Вяч. Ивановым. В части II («О художнике») «Спорад», опубликованной в журнале «Весы» в 1908 г., он указывает на существование двух типов художников: облачителей и разоблачителей, и в числе последних называет Гоголя. Так называемые облачители, «служители высших откровений», знают или догадываются о том, что «высочайшее» в своем изначальном виде не может нам явиться, а чтобы предстать в формах, привычных земному сознанию, оно должное «жертвенно» облечься «в земную сгущенность призрачного вещества» ${ }^{3}$, т. е., иными словами, облечься в образы-символы. Противоположные им по духу художники-разоблачители, напротив, ищут не тайны в земном бытии, не проблесков высшей реальности - они заняты разоблачением правды, срыванием масок, и попутно занимаются профанацией жизни. «Разоблачители, поясняет Вяч. Иванов, - изображают жизнь, отвлекая существенные для их целей признаки от случайных, и потому упрощают жизнь, - упрощают по существу, несмотря на все осложнение ее прагматизма. Они ясны для всех; в разоблачении торжествует именно ясность» ${ }^{4}$.

\footnotetext{
1 Записки Петербургских религиозно-философских собраний. 1901-1903. М.: Республика, 2005. С. 30.

${ }^{2}$ Мережковский Д.С. О причинах упадка и о новых течениях современной русской литературы // Литературные манифесты: От символизма до «Октября». М.: Аграф, 2001. С. 40.

${ }^{3}$ Иванов Вяч. Родное и вселенское. М.: Республика, 1994. С. 77.

${ }^{4}$ Иванов Вяч. Родное и вселенское. С. 76.
} 
В этой претензии, предъявляемой писателям-разоблачителям, отражено то коренное противоречие, которое крайне затрудняло попытку примирения интеллигенции с церковью - в том ее виде, в каком она представлялась русской интеллигенции, - не желающей избавляться от главного своего порока (по мысли ищущих точек соприкосновения с духовенством) - аскетического пренебрежении земной жизнью, традиционного нежелания хотя бы приблизиться к осмыслению антиномии духа и плоти, которой пронизана земная жизнь человека.

Поэтому так неравнодушно была воспринята история взаимоотношений Гоголя с о. Матвеем, в котором создатели будущей религиозной общественности видели олицетворение презирающего живой мир христианства. В этом направлении - в направлении реформирования, правильнее было бы сказать, модернизации христианства - двигались русские символисты, и опыт жизни и творчества Гоголя был как нельзя более кстати в ситуации, когда каждый из них, как в свое время Гоголь, задумывался о поисках компромисса с церковью.

В прочитанном весной 1902 г. докладе «Гоголь и о. Матвей» (прежде опубликованном в журнале «Новый путь») Д.С. Мережковский предпринял попытку расставить все точки над i, анализируя сложные взаимоотношения Гоголя - не с православным священником, воплотившим в себе дух «черного» православия, а с православием, погрузившись в которое Гоголь был обречен на непрекращающийся драматический диалог с самим собой.

Важно отметить, что на предшествующих заседаниях Религиозно-философских собраний острые споры разгорелись по поводу двух тем, имевших исключительное значение для русских модернистов, вырабатывающих не столько эстетические постулаты для нового искусства, сколько новую религию, так как, по убеждению большинства представителей этого направления в русском искусстве, находящаяся в глубоком кризисе церковь уже не в состоянии выполнять возложенные на нее обязанности, а нарождающееся новое искусство может и должно взять выполнение этих обязанностей на себя. Постулируя этот тезис, модернисты считали своим долгом прямо указать духовенству, черному и белому, на пороки исторического христианства, которыми был спровоцирован тягчайший, по их мнению, религиозный кризис. Речь прежде всего шла о той позиции вне мира и земли, которой придерживалась церковь и незыблемость которой отстаивала в споре со своими критиками. Второй важный для модернистов аспект - отсутствие свободы совести и методы духовного насилия, практикуемые, по их убеждению, представителями церкви, и не только церковной бюрократией как таковой, но и духовными пастырями, искренне убежденными в правоте своего дела. И то и другое, противореча принципам модернизма (в редакции старших символистов), провоцировало модернистов на резкие выпады в адрес представителей исторического христианства, поскольку, по их мнению, христианство на современном этапе его существования погрузилось в догматизм, а деятели христианской церкви, вместо того чтобы способствовать развитию религиозной мысли, ставят на ее пути препоны в виде не всегда верно понятого учения отцов церкви. Этим объясняется и выдвижение, в частности, Д.С. Мережковским и его единомышленниками идеи Третьего завета - следующей ступени, на которую должно было подняться христианство. В своем докладе «О церкви грядущего», представленном в Религиозно-философском обществе Петербурга осенью 1907 г., он так формулирует идею Третьего завета: «Третья ступень будет окончательным синтезом объекта и субъ- 
екта, плоти и духа, соединением первого царства Отчего и второго Сыновнего в Третьем царстве Духа Святого, Плоти святой, откровением Трех в Едином» ${ }^{1}$.

Мережковский занят поисками возможности синтеза двух измерений человеческого существования - духовного и плотского - и в этом контексте исследует двойственную (такова его позиция) природу Гоголя, который мечется между любовью к миру и ненавистью к миру. Собственно, вокруг этих проблем и сосредоточиваются на протяжении ряда лет появляющиеся оценки Гоголя-писателя и Гоголя-человека, причем необходимо помнить о том, что для модернистов крайне важен был вопрос ${ }^{2}$ о возможности или невозможности совмещения в человеке творческого начала, побуждающего его бросать вызов богу-творцу своей деятельностью в сфере искусства, и свойственного обыкновенным людям смирения перед Богом, так как для человека главная цель его земного существования - подчиненное внешней, высшей цели, движение вверх, к Богу. Значимость эта проблематика приобретала потому, что идея преображения мира силами искусства (теургизм) стала основой для тех символистов, кто не предполагал ограничиваться эстетическими задачами, и художник-теург призван был сыграть ключевую роль в этом преображении.

Много внимания этому вопросу уделял Вяч. Иванов, видевший - с каждым годом все отчетливее - символизм не столько как эстетическую, но как религиозную программу. Объявив же себя теургами, символисты автоматически попадали в ловушку религиозной дилеммы дух - плоть, выстая реальность-низшая реальность, так как обязывали художника разрешать эти дилеммы, и не в теологическом споре, а в творческом акте. Закономерно вставал вопрос, каким должно быть отношение художника к миру, на который будут направлены его творческие усилиями; для него этот мир - воплощение зла, которое безоговорочно отвергается («Мир за переплетом небесной книги», как заметил Розанов в своей речи об Иисусе сладчайшем), такова была, по мнению модернистов, позиция христиан-традиционалистов. Или создающаяся новая религия - символизм - может предложить и новое решение вопроса о соотношение небесного и земного? Материальный мир - это система символических знаков, указывающих на небесные прообразы земного бытия. То есть в связи с актуализацией религиозной темы, казалось навсегда вытесненной из сознания русской интеллигенции за годы торжества нигилизма, новый смысл приобрел вопрос эстетический - об отношении искусства к действительности, сопряженный с вопросом скорее религиозным: как должен строить свои отношения с миром художник, вступивший на путь религиозного служения.

Занимающий особое положение в кругу русских модернистов ${ }^{3}$, Вяч. Иванов сделал важный шаг в осмыслении внутреннего родства между двумя враждебными «стихиями» - символистской (идеалистической) и реалистической. Для него реализм и идеализм всего лишь моменты в творческом процессе художника, а отнюдь

\footnotetext{
${ }^{1}$ Мережковский Д.С. О церкви грядущего // Религиозно-философское общество в Санкт-Петербурге (Петрограде): История в материалах и документах. 1907-1917: В 3 т. Т. 1: 1907-1909. М.: Русский путь, 2009. С. 115

2 В свете их установки на создание новой религии, как это мыслилось Мережковскому и его адептам, как предполагалось богостроителями-большевиками, а также установки на присвоение искусством функций религии - эта идея была актуальна для русских символистов, прежде всего петербургских, не принимающих ограниченный эстетизм брюсовских «Весов».

${ }^{3}$ По возрасту Вяч. Иванов принадлежал к поколению старших символистов, но свои творческие потенции (как теоретик и глава одной из ветвей в символизме и, конечно же, как поэт) в полной мере реализовал в эпоху младосимволизма.
} 
не выбор генеральной линии его творчества: воспринимая образы, художник - pеалист; воплощая образы -идеалист. Крайне существенным для Иванова оказывается разрушающий художника внутренний конфликт, в основе которого двойственная природа творца, с одной стороны стремящегося, как и всякий человек, ввысь, к Богу, с другой, в силу своей творческой природы, постоянно вынужденного совершать «нисхождения» в земной мир, так как вне контактов с земной реальностью искусство гибнет, художник теряет способность творить, а творчество, в представлении Иванова, должно заключаться в умении художника ознаменовывать явления реального мира - улавливать в нем символические проблески высшей реальности. Этот конфликт - и стремление ввысь, и необходимость нисхождений, - по мысли Иванова, и был причиной целого ряда трагедий, когда попытка отсечь от себя творческое начало (греховное с религиозной точки зрения) оборачивалась деградацией творческого «я», физической гибелью художника. Предлагая свой рецепт спасения, Вяч. Иванов вводит понятия «правого» и «неправого» нисхождения, напоминая о том, что есть оправдание отступлению художника с предначертанного человеку пути: художник, совершая «правое» нисхождение, приносит в мир низких истин истины высокие, напоминая человечеству, как пушкинский Пророк, о Вечности ${ }^{1}$. Если «примерить» предложенную Ивановым схему взаимодействия художника с миром и вечностью на творческую судьбу Гоголя, увидим ту же попытку писателя придать своему влечению к миру характер «правого» нисхождения. На этот момент самооправдания Гоголя обратил внимание в своем докладе Д.С. Мережковский, цитируя одно из писем, адресованных о. Матвею: «Если писателю дан талант, то, верно, недаром и не на то, чтобы обратить его во злое» ${ }^{2}$. Гоголю, как утверждал Мережковский, не до конца открылась эта способная его спасти идея: в искусстве есть начало религиозное, «начало святой плоти», - но и Гоголю уже очевидно было, что «нельзя в мире уйти от мира» .

Мережковский, анализируя судьбу Гоголя, остается в сфере религиозно-общественной проблематики, как и его оппонент в спорах о Гоголе В.В. Розанов. Выступая на заседании Петербургского религиозно-философского общества осенью 1907 г. с докладом «О сладчайшем Иисусе и горьких плодах мира (По поводу статьи Д.С. Мережковского “Гоголь и о. Матвей”)», Розанов, поклонник Ветхого завета и яростный критик Нового, вступает в полемику с Мережковским и теми, кто принимает его оценки взаимоотношений Гоголя с христианством и кто готов увидеть в новозаветном христианстве предпосылку примирения с земным миром, утверждая: «Ни Гоголь, ни вообще литература, как игра, шалость, улыбка, грация, как цветок бытия человеческого, вовсе несовместим с моноцветком, “Сладчайшим Иисусом”. “Но как же тогда мир?” - завоплю я с Мережковским. Как же тогда мы, в цвете и радости своей жизни?» З Заявленная Розановым в своем докладе теза - Христос вытеснил мир, при том что оба они, и Христос и мир, дети одно-

\footnotetext{
1 Эти идеи Вяч. Иванов развивал в 1910-е гг, после объявленного завершения символистского проекта, когда сблизился (в «Трудах и днях») с вечным своим оппонентом Андреем Белым и вместе с ним разрабатывал концепцию неосимволизма, особенно акцентируя его религиозную функцию. ${ }^{2}$ Мережковский Д.С. Гоголь и о. Матвей // Записки Петербургских религиозно-философских собраний. 1901-1903. М.: Республика, 2005. С. 182.

${ }^{3}$ Мережковский Д.С. Гоголь и о. Матвей. С. 182.

${ }^{4}$ Розанов В.В. О сладчайшем Иисусе и горьких плодах мира (По поводу статьи Д.С. Мережковского «Гоголь и о. Матвей» // Религиозно-философское общество в Санкт-Петербурге (Петрограде): История в материалах и документах. 1907-1917: В 3 т. Т. 1: 1907-1909. М.: Русский путь, 2009. C. 142 .
} 
го отца, Бога, - как будто находит подтверждение в трагической гибели Гоголя, выбравшего продиктованный христианством путь аскезы, вместо того чтобы, по Мережковскому, искать возможность синтеза духа и плоти, - или, по Розанову, преодолеть мертвенное дыхание христианства: «С рождением Христа, с воссиянием Евангелия все плоды земные вдруг стали горьки. Во Христе прогорк мир, и именно от Его сладости» ${ }^{1}$, - развивает свою идею Розанов, продолжая в уже названном докладе спор с Мережковским.

Все эти рассуждения о порочности прежнего религиозного идеала и о необходимости его обновления вписываются в общее умонастроение эпохи, пронизанной ренессансным желание обновить доставшиеся в наследство божества, вдохнуть жизнь в образы, извлеченные в ходе «археологических раскопок», предпринятых с целью отыскать в мистической сфере человеческого бытия противоядие для излечения общества и себя самих от материалистического угара, которым была отравлена русская интеллигенция в период торжества позитивизма (в широком значении этого слова).

О распространении подобного рода настроений - усовершенствовать религиозный идеал, придать новый импульс развитию религиозной мысли - свидетельствует и появление религиозно-реформаторских идей в совсем иной среде - в среде революционеров-демократов (большевиков), тех его представителей, которых именовали богостроителями (в отличие от богоискателей из среды модернистов) ${ }^{2}$. Вполне естественным в итоге представляется то, что и не участвующий в заседаниях религиозно-философских собраний и обществ, где дебатировались вопросы современного христианства, Горький, идейный и эстетический противник модернизма, в 1907 г. публикует в «Сборнике товарищества “Знание”» (1908) повесть «Исповедь», по сути повторяющую те претензии, которые предъявляли церкви Д.С. Мережковский, Д.В. Философов, В.В. Розанов, когда отстаивали свою точку зрения в спорах с духовными лицами. Но если социал-демократы - богостроители строили новую (пятую) религию на материале социалистических идей, то их антиподы модернисты для этих целей выбрали искусство, которое и должно было принять на себя функции, в современном мире оказавшиеся не по плечу деятелям церкви, - соединять людей и указывать им путь мистического самопознания, открывающего дорогу к Богу.

Гоголь действительно был чрезвычайно удобен для того, чтобы на примере его судьбы делать выводы о современном состоянии Церкви и строить прогнозы о будущих путях развития не только религиозно-общественной мысли, но и эстетических концепций. Теургический пафос символизма не нашел бы нужной подпитки в идеологии Ф.М. Достоевского или Л.Н. Толстого: оба были слишком уж самостоятельны в своих суждениях, и хотя Л.Н. Толстой в каком-то смысле повторил пройденный Гоголем путь, отказавшись от художественного творчества, но предпосылки этого решения писателя если и имели некоторое отношение к аскезе, то отнюдь не в религиозном ее смысле. Опыт Гоголя, рискнувшего совместить подвиг творчества с религиозным подвигом, был близок модернистам попыткой искомого ими синтеза противоположных начал и, даже неудачно завершенный, был им по-своему полезен.

\footnotetext{
${ }^{1}$ Розанов В.В. О сладчайшем Иисусе и горьких плодах мира. С. 149.

${ }^{2}$ Об этом см.: Певак E.A. Русская философская, религиозная и общественная мысль в конце XIX -

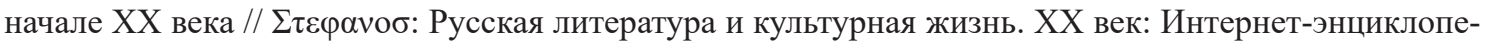
дия (http://www.philol.msu.ru/ modern/).
} 
По мере развития идеологии модернизма, в процессе перехода от идей старших символистов к ориентированной на Вл. Соловьева концепции младосимволистов с их христоцентризмом, гоголевская тема как будто утрачивала свою остроту, но по-прежнему оставалась притягательной для тех авторов, которые всем ходом развития русской литературы поставлены были перед необходимостью разрешить еще одну вечную дилемму, теперь уже в большей степени связанную с эстетической проблематикой: в мажорный или минорный аккорд разрешится дисгармония реализма и идеализма? В этих спорах получила свое развитие религиозно окрашенная вначале полемика о возможности приятия / неприятия художником мира. И теперь уже центр «исследований» переместился в пределы творческого «я», воспринимающего и отражающего действительность, руководствуясь теми эстетическими нормами, которые оказываются для творческой индивидуальности наиболее приемлемыми. Этот сдвиг интересов повлиял на характер оценок уже не столько личности Гоголя, сколько разработанных им приемов воспроизведения действительности в искусстве. Представителями зрелого реализма, упрочившего свои позиции к середине XIX в., Гоголь воспринимался как глава успешно развивающейся реалистической школы, но в начале XX в. реалистичность метода писателя подверглась сомнениям. В его творчестве увидели попытки синтеза двух начал в искусстве - в духе идеореализма, к которому должна была прийти русская литература, наследуя опыт реалистов XIX в. и обогатившись новым миропонимаем, предложенным символистами. Неудачу же Гоголя, вступившего на путь объединения идеализма и реализма, видели прежде всего в особенностях его личного мировосприятия. На это указал Андрей Белый, опубликовавший в юбилейном для Гоголя 1909 г. в журнале «Весы» статью, где подробно проанализировал свойственные писателю приемы письма, свидетельствующие, как считал Белый, о неспособности его, воспроизводя реальный мир, сохранить духовно-телесную целостность этого мира. В творческом сознании Гоголя, утверждал Белый, земной мир поделен на две чуждые друг другу сферы. «Гоголь оторвался от того, что мы называем действительностью, - пишет Белый. - Кто-то из-под ног его выдернул землю; осталась в нем память о земле: земля человечества разложилась для него в эфир и навоз (выделено нами. - E.П.); а существа, населяющие землю, превратились в бестелесные души, ищущие себе новые тела: их тела не тела - облачный туман, пронизанный месяцем... И все человеческие чувства (как-то: любовь, милосердие, радость) отошли для него в эфир...» ${ }^{1}$.

В том же номере «Весов» (№ 4 за 1909 г.) напечатана была характеристика, данная Гоголю В. Брюсовым, весьма показательно названная - «Испепеленный». Подчеркнув присущие Гоголю экстаз и безмерность, гиперболизм как в восприятии окружающего мира, так и в созданных его фантазией образах, Брюсов, не обходя вниманием отмеченную неоднократно гоголевскую раздвоенность души, подойдя к последним трагическим дням жизни писателя, пишет об обретенной им гармонии, когда та сторона его души, которая позволяла ему творить, свободно предаваясь экстазу, теперь и в собственной его жизни приобрела черты безмерности, беспредельности. Раскрепощенная воля писателя (теперь уже не творческая - жизненная), вырвавшись на свободу, испепелила его.

Хотя Брюсов скептически воспринимал попытки своих соратников по символизму выстроить на базе этой эстетической школы некую мировоззренческую концепцию, близкую по структуре и по содержанию к религиозной, и ему была не чужда знакомая многим его современникам жажда саморазрушения, что одними

${ }^{1}$ Бельй А. Гоголь // Белый А. Символизм как миропонимание. М.: Республика, 1994. С. 364. 
мыслилось в контексте ницшеанства, другими - Апокалипсиса. Для младосимволистов и близкого им по мироощущению Вяч. Иванова Гоголь представляет собой не объект, испытавший разрушительное воздействие пленившей его христианской идеи, - он самостоятелен и самодостаточен, и трагическая его судьба результат не заблуждений, инспирированных извне, а итог его внутреннего выбора.

Характерное для младосимволистов стремление к саморасточению, идея искупительной жертвы, принесенной во имя высокой цели - рождения нового мира, чему всячески должно способствовать символистское искусство, ведущее человечество - быть может, обрекая его и себя на гибель во имя будущего воскрешения мира, - всё это уводит в сторону от того критического восприятия христианства, которое демонстрировали старшие символисты, когда вступали в обсуждение проблемы будущего религии на совместных с духовенством заседаниях в начале 1900-х гг. Если сравнить саму тональность выступлений интеллигенции в религиозно-философских собраниях и в религиозно-философском обществе, увидим перемены: вместо желания перестроить религию и религиозную общественность под себя по определенному рецепту - готовность признать, что, обращая к Церкви вопросы, по сути те же, что и прежде, сама интеллигенция готовых ответов на эти вопросы не имеет. Показательно в этом отношении выступление А.А. Блока осенью 1908 г. в Петербургском религиозно-филососком обществе с докладом «Россия и интеллигенция». Отталкиваясь от прочитанного там же Германом Бароновым доклада «О демотеизме (обожествление народа в "Исповеди" Максима Горького)», Блок, характеризуя перемены в миросозерцании Горького, делает обобщающие выводы, фиксируя перемены в настроениях русской интеллигенции в целом, и главным его выводом можно считать слова: «Вслед за русской литературой, Горький отказывается проповедовать; он только смятенно ищет» ${ }^{1}$. Своими рассуждениями Блок выводит Горького из сферы влияния богостроителей-большевиков, утверждая, что больше родства у этого писателя «не с Луначарским, а с Гоголем; не с духом современной “интеллигенции”, но с духом “народа"»².

Смещение акцента в оценке Гоголя обусловлено пересмыслением символистами своей роли - и в сфере религиозно-общественной деятельности, и в сфере искусства, которое из самостоятельного проекта модернистов превращается в некое общее дело, временные и пространственные границы бытования которого находятся далеко за пределами интеллигентского сознания. Гоголь в контексте этого изменившегося самосознания творческой интеллигенции, примыкающей к модернизму, предстает уже не жертвой аскетического православия, а гением, которому удалось приблизиться к миру русской души, так часто ускользающей от жаждущих встречи с ней современников Блока.

Созданный Гоголем в «Мертвых душах» образ русского мира, обреченного на поиски идеала и непрестанно совершающего ошибки на этом пути, оказался близок сознанию символистов, переживающих крах выдвинутых символизмом идей и в качестве спасательного круга - по давней нашей традиции - выбирающих русскую народную идею, в основе своей религиозную, но с отчетливо выраженным апокалиптическим началом, хотя и содержащим своеобразную оптимистическую ноту: погибнешь - и затем воскреснешь.

\footnotetext{
${ }^{1}$ Блок А.А. Россия и интеллигенция // Религиозно-философское общество в Санкт-Петербурге (Петрограде): История в материалах и документах. 1907-1917: В 3 т. Т. 1: 1907-1909. М.: Русский путь, 2009. С. 361.

${ }^{2}$ Блок А.А. Россия и интеллигенция. С. 362.
} 
Поставленный Вяч. Ивановым диагноз - «мы нация самосожигателей» - подтверждается рассуждениями Блока об ожидающей интеллигенцию, устремившуюся в поисках спасения к народу, судьбе: «Что, если тройка, вокруг которой “гремит и становится ветром разорванный воздух", - летит прямо на нас? Бросаясь к народу, мы бросаемся прямо под ноги бешеной тройке, на верную гибель» ${ }^{1}$. Впрочем, блоковская концепция жертвы, неизбежной и желанной, в духе гоголевского самопожертвования, уравновешивается в символизме на завершающем этапе его существования концепцией Вяч. Иванова, выдвинувшего идею всенародного искусства, которое возникнет при условии выхода художника из пределов индивидуального стиля, что тоже предполагает самопожертвование, т. е. отказ от своего творческого «я», но итогом станет не его гибель, а перемещение на более высокую ступень творческого постижения мира.

Такая трансформация творческого «я», способного объять не узко очерченный субъективным восприятием мирок, но предложить многомерную и многослойную картину действительности, намеченная в ряде работ Вяч. Иванова, получает развитие в концепциях постсимволизма, в частности, в рассуждениях близких к «Аполлону» авторов и критиков о «вершинном» романе, где гармонично соединятся реалистическая достоверность в отражении всего многобразия жизни и отточенное символизмом умение проникать в суть вещей, видеть в происходящем не поверхностное течение жизни, а отражение сложных духовных процессов, в которые вовлечены все. Можно говорить о том, что предложенное Гоголем в «Мертвых душах» целостное изображение процессов частного характера и вселенского масштаба (что, конечно же, характерно и для Достоевского, и для Л. Толстого) в определенном смысле становится образцом для авторов, которые в 1910-е гг. предпринимают попытки перейти от «осколочного», в духе Чехова, изображения действительности к крупным эпическим формам. Прежде всего следует упомянуть «Серебряного голубя», а затем и «Петербург» А. Белого - автора, который близко подошел к гоголевской традиции. Но важно указать на то, что в постсимволистскую эпоху это было общей тенденцией. В предложенном М.А Кузминым обзоре «Художественная проза “Весов"», опубликованном в 1909 г. в «Аполлоне», дана характеристика новому роману, ориентированному на гоголевскую прозу. Упоминая «Серебряного голубя» Белого как одно из лучших его произведений, в котором указан «путь широкой символико-реалистической картины современной России», Кузмин отмечает важную черту этой новой прозы - «большое и острое чувствование современной России» ${ }^{2}$, и в один ряд с Белым ставит других авторов, выбравших ту же дорогу: А. Ремизова, А. Толстого, М. Горького (в некоторых вещах).

Подытоживая сказанное, отметим динамику в восприятия феномена гоголевского творчества русскими модернистами, оценка которых интересна тем, что связанная с Гоголем проблематика оказалась весьма востребованной на этапе ренессансного подъема русской культуры на рубеже XIX-XX вв.

Скептическое отношение к Гоголю, прежде всего как к религиозно-общественному мыслителю, в среде русской интеллигенции сформировалось в середине XIX в., после публикации им «Выбранных мест из переписки с друзьями» (1847). И если прежде можно было, как поступали В.Г. Белинский и его единомышлен-

\footnotetext{
${ }^{1}$ Блок А.A. Россия и интеллигенция. С. 367.

${ }^{2}$ Кузмин М.А. Художественная проза «Весов» // Кузмин М.А. Проза и эссеистика: В 3 т. Т. 3: Эссеистика. Критика. М.: Аграф, 2000. С. 15.
} 
ники, игнорировать реакцุионные взгляды писателя, беря на вооружение разработанные им принципы и модели отражения действительности в искусстве, то после выхода книги, где автор со всей определенностью высказался против идеи реформирования России, ситуация изменилась: Гоголь - религиозный мыслитель оказался в забвении. Из небытия писателя «извлекли» модернисты, которые, решая важные для самих себя вопросы, в судьбе Гоголя, личной и творческой, находили или аргументы для подтверждения собственной правоты в спорах с противниками, или материал для раздумий о собственной судьбе, или прообраз тех художественных форм, которые позволили бы им воплощать свое ви́дение русской жизни.

\section{ЛИТ Е РАТ У РА}

Белый А. Гоголь // Белый А. Символизм как миропонимание. М.: Республика, 1994. C. $361-371$.

Бенуа А.Н. Мои воспоминания: В 5 кн. Книги четвертая, пятая. 2-е изд., доп. М.: Наука, 1990. $743 \mathrm{c}$.

Блок А.А. Россия и интеллигенция // Религиозно-философское общество в Санкт-Петербурге (Петрограде): История в материалах и документах. 1907-1917: В 3 т. Т. 1: 19071909. М.: Русский путь, 2009. С. 359-367.

Иванов Вяч. Спорады. Ч. 2: О художнике // Иванов Вяч. Родное и вселенское. М.: Республика, 1994. С. 75-77.

Кузмин М.А. Художественная проза «Весов» // Кузмин М.А. Проза и эссеистика: В 3 т. Т. 3: Эссеистика. Критика. М.: Аграф, 2000. С. 10-16.

Мережковский Д.С. Гоголь и о. Матвей // Записки Петербургских религиозно-философских собраний. 1901-1903. М.: Республика, 2005. С. 174-190.

Мережковский Д.С. О причинах упадка и о новых течениях современной русской литературы // Литературные манифесты: От символизма до «Октября». М.: Аграф, 2001. C. 34-41.

Мережковский Д.С. О церкви грядущего // Религиозно-философское общество в Санкт-Петербурге (Петрограде): История в материалах и документах. 1907-1917: В 3 т. Т. 1: 1907-1909. М.: Русский путь, 2009. С. 113-117.

Певак E.A. Русская философская, религиозная и общественная мысль в конце XIX - на-


клопедия (http://www.philol.msu.ru/ modern/).

Розанов В.В. О сладчайшем Иисусе и горьких плодах мира (По поводу статьи Д.С. Мережковского «Гоголь и о. Матвей» // Религиозно-философское общество в Санкт-Петербурге (Петрограде): История в материалах и документах. 1907-1917: В 3 т. Т. 1: 19071909. М.: Русский путь, 2009. С. 139-151.

\section{RE F E R E N CES}

Bely A. Gogol. In: Bely A. Symbolism as a Worldview. Moscow. Respublika Publ. 1994, pp. 361-371.

Benois A.N. My Memories: In 5 books. Books Fourth, Fifth. $2^{\text {nd }}$ ed., suppl. Moscow. Nauka Publ. 1990. 743 p.

Blok A.A. Russia and the Intelligentsia. In: Religious-philosophical Society in St. Petersburg (Petrograd): History in Materials and Documents. 1907-1917: In 3 vols. Vol. 1: 19071909. Moscow. Russky Put Publ. 2009, pp. 359-367. 
Ivanov Vyach. Sporady. Part 2: About the Artist. In: Ivanov Vyach. Native and Universal. Moscow. Respublika Publ. 1994, pp. 75-77.

Kuzmin M.A. Prose Oeuvre in "Vesy". In: Kuzmin M.A. Prose and Essays: In 3 vols. Vol. 3 : Essays. Critique. Moscow. Agraf Publ. 2000, pp. 10-16.

Merezhkovsky D.S. Gogol and Priest Matvey. In: Notes of St. Petersburg Religious-philosophical Meetings. 1901-1903. Moscow. Respublika Publ. 2005, pp. 174-190.

Merezhkovsky D.S. The Cause of Decline and New Trends in Modern Russian Literature. In: Literary Manifestos: From Symbolism to "October". Moscow. Agraf Publ. 2001, pp. 34-41.

Merezhkovsky D.S. About the Church of the Forthcoming. In: Religious-philosophical Society in St. Petersburg (Petrograd): History in Materials and Documents. 1907-1917: In 3 vols. Vol. 1: 1907-1909. Moscow. Russky Put Publ. 2009, pp. 113-117.

Pevak E.A. Russian Philosophical, Religious and Social Thought in the late XIX - early XX century. In: $\Sigma \tau \varepsilon \varphi \alpha v o \sigma$ : Russian Literature and Cultural Life. The $20^{\text {th }}$ century: Internet Encyclopedia (http://www.philol.msu.ru/ modern/).

Rozanov V.V. About the Sweetest Jesus and the Bitter Fruits of the World (On D.S. Merezhkovsky's Article "Gogol and Priest Matvey". In: Religious-philosophical Society in St. Petersburg (Petrograd): History in Materials and Documents. 1907-1917: In 3 vols. Vol. 1: 19071909. Moscow. Russky Put Publ. 2009, pp. 139-151.

Сведения об авторе:

Елена Александровна Певак,

канд. филол. наук

научный сотрудник

филологический факультет

МГУ имени М.В. Ломоносова
Elena A. Pevak,

$\mathrm{PhD}$

Research Associate

Philological Faculty

Lomonosov Moscow State University

epevak@yandex.ru 